\title{
SYMPOSIUM G
}

\section{Materials Characterization Applied To Utilization, Immobilization, And Disposal Of Solid Wastes}

This symposium covered the broad area of materials characterization applied to the utilization, immobilization, and disposal of solid wastes from the combustion or conversion of coal, from the chemical industry, and from municipal sources. The symposium attracted some very stimulating papers and strong interaction among leading research groups in the U.S. and abroad in several areas.

The largest of these areas was the characterization and utilization of solid wastes from coal combustion and gasification. Materials characterization of fresh and treated ash with modern X-ray diffraction and electron optical methods was described by R.J. Lauf (ORNL), R.J. Stevenson and D.R. Sears (University of North Dakota), G.J. McCarthy (North Dakota State), and L.D. Hulett (ORNL).

In a keynote talk, $S$. Diamond (Purdue) reviewed the utilization of fly ash in the U.S. He noted that only 10-15 percent of the ash produced each year is now being used, with the chief applications being cement replacement in concrete and soil stabilization for highway or mine haul road construction. The balance of the ash is buried, at considerable expense to the utilities. Considerably more of the available fly ash is utilized in Europe, as noted by G. Idorn from Denmark. Idorn and K.R. Henricksen described one valuable application of fly ash in the fabrication of high strength concrete in bridge support structures in Denmark. B.E. Scheetz (Penn State) and K. Schrivener and P.L. Pratt (Imperial College, London) described the interplay of microstructure, hydration behavior, and strength of cement incorporating fly ash. A critical review of the role of lime in the pozzolonic activity of high-calcium fly ash was presented by $T$. Demirel (Iowa State). Materials characterization applied to additional uses of fly ash in slag cements, mineral wool, ceramics, and soil stabilization was described by R.M. Roy (Penn State), O. Manz (University of North Dakota), and S. Schlorholtz (Iowa State University).

Two additional session were offered in Symposium G. S.L. Blum organized a session on municipal waste which included three papers on calorific measurements and data on refuse derived fuels presented by E.S. Domalski and coworkers at NBS and on segregation of nonferrous metals by magnetic methods given by E. Schloemann (Raytheon). In the session keynote talk, D.K. Walter (DOE) gave a broadbased review of the current state of recovery of materials and energy from municipal waste. He noted that the recent stabilization and reductions in energy and base metal prices, along with problems in plant siting, have caused such recovery to be much less than was envisaged in the mid 1970s. The fourth session in the symposium included two papers from workers at Penn State (R. Roy, W.B. White, B.E. Scheetz, et al.) on innovative approaches to chemical waste stabilization in low leachability solids.

\section{G.J. McCarthy}

North Dakota State University

B.E. Scheetz

Pennsylvania State University

S.L. Blum

Northern Energy Corp.

Chairmen

\section{MATERIALS EDUCATION}

Educational Modules for Materials Science and Engineering, or EMMSE, is a not-for-profit, periodic publication for materials educators. These materials are prepared by an international body of materials scientists and engineers concerned with producing first-rate materials and distributing them copyright-free at minimal cost.

Originated by Rusty Roy's indefatigable Materials Research Lab at Penn State, EMMSE and its companion Journal of Materials Education publish articles on a broad range of subjects. Among current offerings:

- EMMSE modules (the equivalent of textbook chapters, though in formats that often include audio-visual or other presentations) on crystallography (a nine-unit mini-course, of which about 10,000 units are distributed worldwide every year); laboratory experiments in polymer synthesis and characterization; wood: its structure and properties; wood as a structural material; adhesive bonding of wood and other structural materials; and cement.

- "Magisterial" reviews by world authorities on the "Frontiers of Materials Science" (in the Journal of Materials Education).

- The Media Index, updated periodically, which is an annotated index of all audio-visual programs in materials science. 